\title{
RANCANG BANGUN MESIN PEMBUAT RUJAK ES KRIM KAPASITAS 120 CUP/JAM BAGI UMKM DI SURABAYA BARAT
}

\author{
Slamet Riyadi', Muhammad Nur Rohman ${ }^{2}$, Ahmad Tajol Mahasin ${ }^{3}$ \\ ${ }^{1}$ Universitas Wijaya Putra \\ ${ }^{2}$ Universitas Wijaya Putra \\ ${ }^{3}$ Universitas Wijaya Putra \\ slametriyadi@uwp.ac.id, 16051035@students.uwp.ac.id, 16051033@students.uwp.ac.id
}

\begin{abstract}
Abstrak
Kuliner rujak es krim memang masih awam dan belum banyak orang tahu. Tak banyak masyarakat berdagang rujak es krim yang dibuat secara manual yang berdampak kwalitas es krim nya kurang optimalnya dan banyak mengeluarkan waktu. Tujuan dibuat mesin rujak es krim ini adalah supaya untuk meningkatkan kwalitas rujak es krim dan meminimalisir waktu dalam pembuatannya sehingga menuai hasil yang maksimal. Cara membuat rujak es krim ini mula-mula buah dikupas dan dipotong kecil, lalu dimasukkan kedalam gelas. Setelahnyadimasukkannya bumbu rujak kedalam cup dan terakhir diberi tiga sampai empat sekop es krim diatanya. Dalam hal ini penyusun berinovasi melakukan pembuatan mesin berbasis pneumatik untuk pemotong buah dan membuat mesin es krim yang praktis dalam pengoperasiannya. Dari dua sistem kerja itu akan digabung di satu kerangka berbahan besi yang dapat menghasilkan mesin rujak es krim, sehingga akan lebih membantu dalam segi waktu dan kualitasnya. Permasalahan yang ada pada UMKM: 1) masih cara manual/tradisional, 2) produksi rendah dan permintaan banyak, 3) penjualan dan pemasaran masih standart, 4) Rasa kurang halus. Metode pelaksanaan: Metode yang di gunakan otomatisasi Mesin Teknologi Tepat Guna dengan system pneumatis. Hasil pengabdian ini: meningkatkan produksi dan pendapatan karena menggunakan otomasi tekonologi mesin tepat peningkatan kapasitas produksi. Metode pengabdian berupa pelatihan teknologi mesin es rujak es krim. Sedangkan hasil pengabdian ini UMKM juga mengimplementasikan otomasi mesin teknologi guna agar harga selalu terjangkau konsumen.
\end{abstract}

Kata Kunci : teknologi tepat guna, rujak es krim, umkm

\section{PENDAHULUAN}

Pertumbuhan kuliner di nusantara terbilang cukup pesat dan sukses. Beragam bidang kuliner memiliki segmentasi pasar masing-masing, mulai dari makanan hingga minuman. Salah satu bidang kuliner yang memiliki segmentasi pasar yang luas adalah es puter atau biasa kita kenal dengan nama es krim. Meskipun beberapa produsen es krim didominasi oleh perusahaan besar, namun terdapat beberapa industi rumahan yang mulai membidik usaha es krim tersebut. Perkembangan usaha rumahan yang semakin banyak memerlukan pembinaan dan pelatihan yang berorientasi nilai tambah untuk meningkatkan daya saing dalam penjualannya. Es puter atau es krim adalah produk makanan beku yang dibuat melalui kombinasi proses pembekuan dan agitasi pada bahan-bahan yang terdiri dari susu dan produk susu, pemanis, penstabil, pengemulsi, serta penabah cita rasa. Selain terbuat dari komposisi diatas, sering kita jumpai es krim terbuat dari bahan dasar santan kelapa, gula pasir, campuran tepung maizena dan bahan tambahan

$$
\text { Teknologi Tepat Guna }
$$


lainnya. es krim itu sendiri dikenal sejak zaman Romawi, yaitu pada 400 tahun Sebelum Masehi. Produksi es krim secara komersial mulai dilakukan pada abad ke-18,menyusul ditemukannya mesin freezer pada tahun 1846. Pabrik es krim pertama dibangun di Baltimore,Amerika Serikat, pada tahun 1851. Es krim dapat dikatakan sebagai jenis hidangan paling populer di dunia. Pada tahun 2003, produksi es krim dunia mencapai lebih dari satu miliar liter dan dikonsumsi oleh miliaran konsumen per tahun. Menurut Standar Nasional Indonesia, es krim adalah sejenis makanan semi padat yang dibuat dengan cara pembekuan tepung es krim atau campuran susu, lemak hewani maupun nabati, gula, dan dengan atau tanpa bahan makanan lain yang diizinkan. Struktur dan kandungan es krim tidak lain berupa busa (gas yang terdispersi dalam cairan) yang diawetkan dengan pendinginan. Walaupun es krim tampak sebagai wujud yang padu, bila dilihat dengan mikroskop akan tampak ada empat komponen penyusun, yaitu padatan globula lemak susu, udara (yang ukurannya tidak lebih besar dari $0,1 \mathrm{~mm}$ ), kristal-kristal kecil es, dan air yang melarutkan gula, garam, dan protein susu. Berbagai standar produk makanan di dunia membolehkan penggelembungan campuran es krim dengan udara sampai volumenya menjadi dua kalinya (disebut dengan maksimum 100 persen overrun). Es krim dengan kandungan udara lebih banyak akan terasa lebih cair dan lebih hangat sehingga tidak enak dimakan. Bila kandungan lemak susu terlalu rendah, akan membuat es lebih besar dan teksturnya lebih kasar serta terasa lebih dingin. Emulsifier dan stabilisator dapat menutupi sifat-sifat buruk yang diakibatkan kurangnya lemak susu dan dapat memberi rasa lengket. es krim merupakan salah satu makanan beku/dingin yang sangat digemari oleh berbagai kalangan. Produk ini terdiri atas campuran bahan-bahan yang banyak mengandung protein tinggi seperti telur dan susu. Lebih lanjut Usmiati dan Abubakar (2009), menjelaskan apabila es krim dikeluarkan dari freezer selama beberapa waktu akan terjadi sineresis/mencairnya padatan, oleh karena itu perlu ditambahkan bahan penstabil untuk memperlambat terjadinya sineresis tersebut. Kekentalan es krim banyak dipengaruhi oleh komposisi adonan, jenis dan kualitas bahan, proses penanganan atau suhu dan kadar lemak bahan. Goff dan Hartel (2013) menjelaskan jumlah dan jenis stabilizer atau emulsifier campuran yang dibutuhkan alam es krim bervariasi dengan campuran komposisi, bahan yang digunakan, waktu pengolahan, suhu, dan tekanan; suhu penyimpanan; dan berbagai faktor lainnya. Umumnya, saran terbaik adalah mengikuti rekomendasi dari pemasok. Takaran stabilizer / emulsifier yang digunakan dalam campuran es krim biasanya $0,2-0,5 \%$ dari adonan. Mengikuti perkembangan zaman yang terus menerus melakukan inovasi, penyajian es krim yang biasanya disajikan dalam beraneka ragam bentuk (di gelas, cone, piring kecil, dll), kini tak asing lagi es krim disajikan dengan kombinasi rujak buah dengan bumbu sedang sampai dengan bumbu pedas. Berdasarkan hasil survey di lapangan, khususnya di lingkungan Surabaya Barat, terdapat pedagang es krim yang menjajakan es krimnya dengan rujak manis, tepatnya adalah pedagang rujak es krim yang beralamatkan di Jl. Raya Benowo no. 40 Pakal Surabaya. Mengamati proses pembuatannya, mulamula buah yang sudah dikupasdipotong kecil-kecil secara manual, lalu di sajikan dalam wadah cup gelas, setelah itu bumbu rujak dituangkan kedalam cup gelas sesuai selera pedas atau tidaknya. Setelah bumbu rujak dituangkan, dimasukkan nya es krim dari tabung kedalam cup gelas dengan cara manual, yaitu dengan memutar tabung es krim dan mengambil es krim tersebut disekop menggunakan sendok es krim khusus

Berdasarkan latar belakang serta mengamati proses pembuatan rujak es krim yang dilakukan secara manual diatas, dari situ penulis melakukan pengembangan produk yaitu dengan perancangan mesin pembuat rujak es krim. Mesin rujak es krim tersebut tergabung dari mesin pemotong buah, penuang bumbu rujak dan mesin pembuat es krim yang hal itu dapat meningkatkan efesiensi bagi pedagang rujak es krim.

\section{METODE}

Diagram alir pembuatan mesin pembuat Rujak Es Krimdengan sistem pneumatik seperti di bawah ini : 


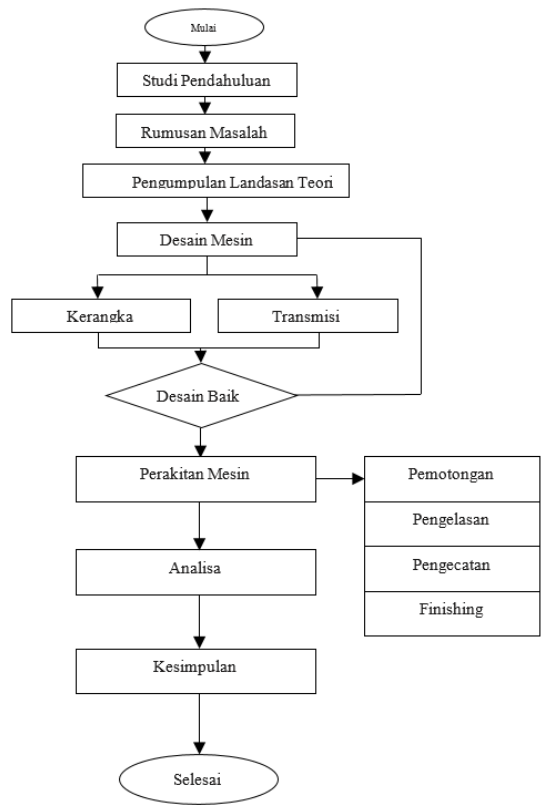

Gambar 1 : Diagram alur perencanaan, perakitan, dan pengujian Mesin Pembuat Rujak Es Krim

Kapasitas 120 Cup/Jam

\section{Konsep dan Perancangan Mesin Pembuat Rujak Es Krim}

Desain konsep mesin rujak es krim otomatis berbasis pneumatik sangat diperlukan dalam sebuah perancangan. Desain konsep meliputi bentuk dasar, dimensi utama yang fungsional, dan mekanisme kerja. Konsep perancangan ini memberikan gambaran awal mengenai alat yang akan dibuat dan bagaimana mekanisme kerja dengan mempertimbangkan kesesuaian operator atau pekerja yang akan menggunakannya.

Konsep desain dari mesin rujak es krim otomatis berbasis pneumatik ini adalah gambaran secara garis besar mengenai mesin rujak es krim otomatis berbasis pneumatik yang akan dibuat, mempermudah perhitungan teknik seperti penentuan dimensi komponen, dan peletakkan komponen pendukung itu sendiri. Adapun spesifikasi dari perancangan mesin rujak es krim otomatis berbasis pneumatik adalah sebagai berikut :

Panjang : $90 \mathrm{~cm}$, Lebar : $50 \mathrm{~cm}$, Tinggi : $95 \mathrm{~cm}$

Penggerak : Motor $1310 \mathrm{rpm}, 0,25 \mathrm{HP}$

\section{Desain Rangka Mesin}

Rangka mesin adalah suatu komponen mesin rujak es krim otomatis berbasis pneumatik yang berfungsi sebagai penopang berdirinya seluruh komponen pada mesin es puter. Rangka ini dibuat dengan menggunakan bahan dasar berbentuk profil hollow. Besi profil hollow digunakan untuk membuat rangka kaki karena material jenis ini memliki konstuksi yang kuat tetapi ringan.

Agar dapat menopang berdirinya mesin rujak es krim otomatis berbasis pneumatik keempat rangka kaki ini dihubungkan dengan konstruksi penopang dengan menggunakan las. Penggabungan rangka kaki dengan konstruksi penopang akan ditunjukan pada gambar dibawah ini.

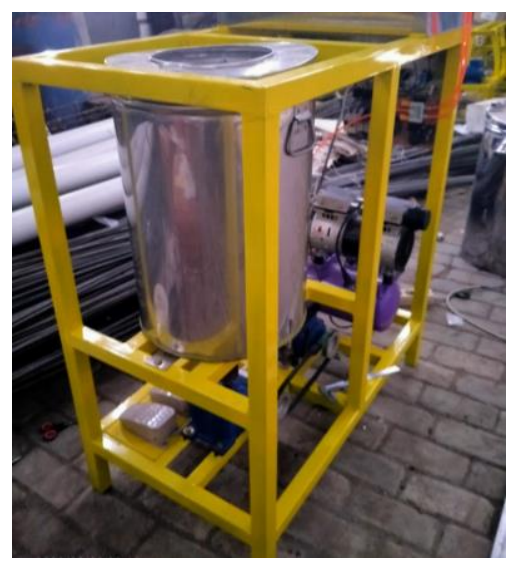

Gambar 2. Rangka mesin rujak es krim otomatis berbasis pneumatik

\section{Perancangan Motor dan Transmisi Penggerak Motor Penggerak}

Motor Berfungsi sebagai sumber daya penggerak mesin es puter. Motor yang digunakan dalam perancangan mesin ini adalah motor AC 0,25 HP dengan putaran $1310 \mathrm{rpm}$. Alasan pemilihan motor ini adalah jika dibandingkan dengan motor dengan 
jumlah HP yang lebih kecil, maka umur pakai motor yang digunakan akan sangat singkat, lihat gambar dibawah:

Penempatan motor pada mesin rujak es krim otomatis berbasis pneumatik terdapat pada bawah rangka secara horizontal agar pada saat pemasangan sabuk dari pulley yang ada pada motor ke pulley yang ada pada gearbox bisa dengan mudah. Gambar berikut ini menunjukan gambar motor yang digunakan pada mesin rujak es krim otomatis berbasis pneumatik.

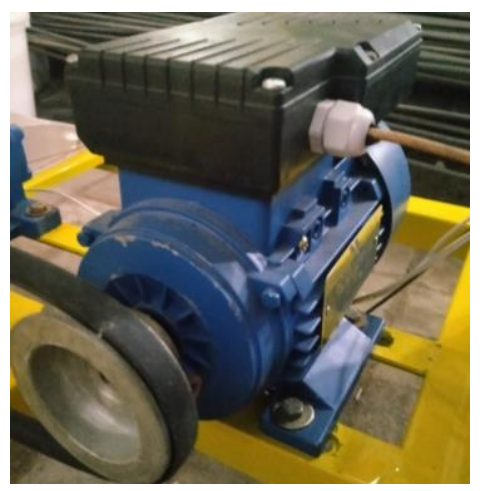

\section{Gearbox}

Gambar 3. Motor 1310 rpm

Komponen ini berfungsi sebagai pemindah daya dari motor sekaligus sebagai pereduksi kecepatan motor dari putaran yang lebih tinggi ke putaran yang lebih rendah. Adapun alasan penggunaan gearbox ini dikarenakan pada pembuatan es krim tidak membutuhkan putaran dengan rpm yang cukup tinggi. Dengan menggunakan gearbox dengan ukuran 1 : 30 maka kecepatan motor dari putaran $1310 \mathrm{rpm}$ dapat di reduksi menjadi $44 \mathrm{rpm}$. Gambar berikut ini menunjukan gambar gearbox yang digunakan pada mesin es puter.

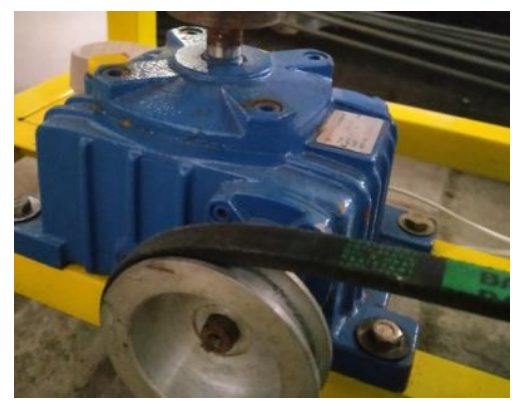

\section{Gambar 4. Gearbox tipe WPO}

\section{Pulley}

Pulley selain sebagai salah satu komponen yang utama dari mesin es puter juga berfungsi sebagai tempat untuk sabuk dengan tipe $\mathrm{V}$ yang fungsinya adalah mentransmisikan daya putaran motor dari pulley yang berada pada motor ke pulley yang berada pada gearbox, adapun dimensi dari pulley tersebut yang diambil adalah dengan diameter 75 $\mathrm{mm}$ berjumlah 2 buah. Berikut merupakan gambar dari pulley yang ditunjukan pada gambar

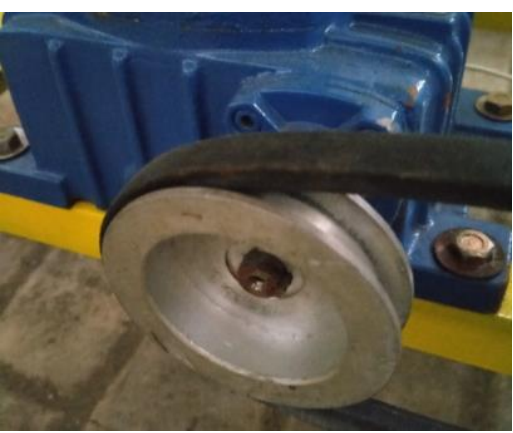

Gambar 5. Pulley

\section{V-Belt}

Penggunaan komponen ini pada mesin rujak es krim otomatis berbasis pneumatik adalah sebagai penerus putaran dari pully motor listrik menuju ke pully gearbox. V-belt yang digunakan berdiameter $82 \mathrm{~cm}$. Gambar dibawah ini adalah penampakan V-belt yang dipakai pada mesin rujak es krim otomatis berbasis pneumatik.

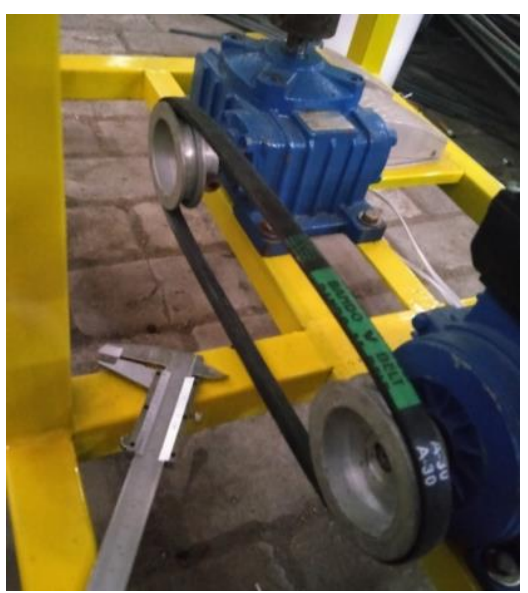

Gambar 6. V-belt

\section{Kopling Penerus}


Kopling dalam mesin rujak es krim otomatis berbasis pneumatik ini berfungsi sebagai penyambung antara poros output gearbox yang diteruskan ke poros penggerak tabung es krim. Kopling yang di pakai adalah kopling tipe L090B dengan ukuran diameter $540 \mathrm{~mm}$, pada kopling bawah dibubut $174 \mathrm{~mm}$ untuk masuk ke dalam poros gearbox dan bagian atas dibubut 250mm untuk masuk pada poros penggerak tabung es krim, lihat gambar di bawah ini:

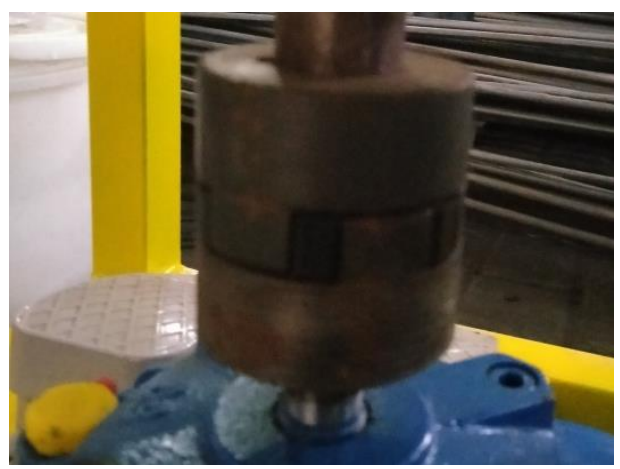

Gambar 7. Kopling penerus

\section{Poros penggerak tabung}

Poros yang dimaksud disini adalah poros yang berfungsi sebagai penggerak tabung dalam. Poros disini sudah dimodif dengan ukuran diameter $250 \mathrm{~mm}$ dan panjang $18 \mathrm{~cm}$.

Pada bagian atas poros ditambahi plat custom sebagai flange pemutar tabung es krim pada mesin mesin rujak es krim otomatis berbasis pneumatik. Gambar berikut ini menunjukan gambar poros yang digunakan pada mesin rujak es krim otomatis berbasis pneumatik.

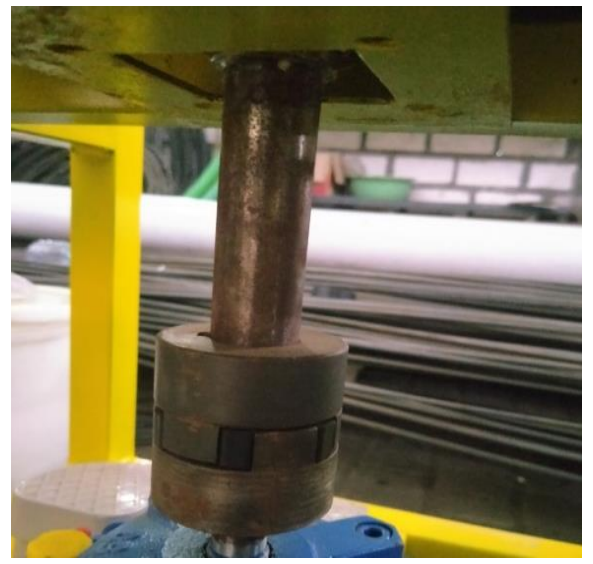

Gambar 8. Poros penggerak tabung

\section{Tabung}

Tabung berfungsi sebagai wadah adonan yang diputar melalui poros dengan cara ditempatkan tepat pada as poros pemutar dimana pada bagian bawah tabung sudah dimodifikasi agar tabung dapat ikut berputar dengan poros pemutar. Dimensi tabung dalam antara lain diameter $200 \mathrm{~mm}$ dengan tinggi $500 \mathrm{~mm}$, sedangkan dimensi tabung luar adalah berdiameter $350 \mathrm{~mm}$ dan tinggi $500 \mathrm{~mm}$. Gambar dibawah ini merupakan gambar tabung.

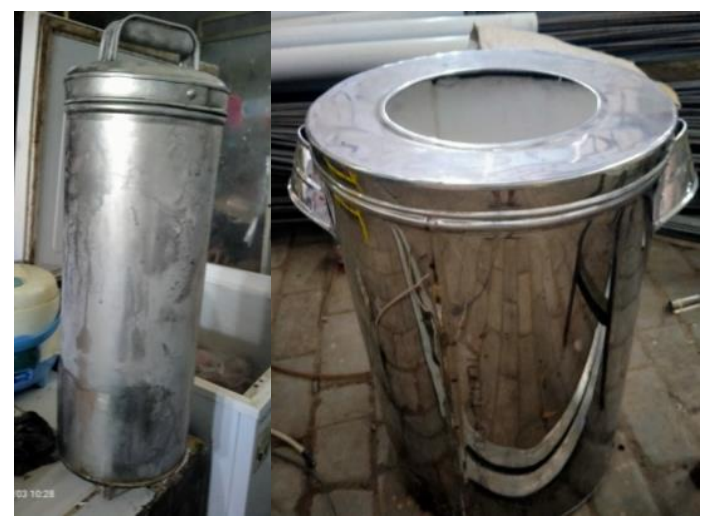

Gambar 9. Kopling tabung

\section{HASIL DAN PEMBAHASAN}

Pada tahapan perhitungan mekanik mesin mesin rujak es krim otomatis berbasis pneumatik perlu dilakukan perhitungan yang nantinya akan digunakan dalam rancangan mesin mesin rujak es krim otomatis berbasis pneumatik, perhitungan yang dilakukan antara lain :

\section{Pemilihan Daya}

Daya motor listrik yang ditransmisikan dihitung dengan faktor koreksi, untuk memperoleh daya rencana,karena daya motor yang digunakan adalah daya normal dan kejutan terjadi hanya pada saat awal pembebanan (Sularso dan Suga, K., 1997), maka faktor koreksi daya diambil dari harga faktor koreksi pada saat daya maksimum, dengan harga 0,8 sampai 1,2. Harga faktor koreksi yang diambil sebesar 1,0, maka daya rencana dapat ditentukan tetapi terlebih dahulu dicari kapasitas maksimal tabung :

$\mathrm{Va}=\mathrm{La} \times \mathrm{t}$

Keterangan :

La: Luas alas dari tabung

$$
\text { Teknologi Tepat Guna }
$$


T: tinggi tabung $=500 \mathrm{~mm}=5 \mathrm{dm}$

D: diameter tabung $=200 \mathrm{~mm}=2 \mathrm{dm}$,Jadi :

$\mathrm{Va}=3,14 \times(1 \mathrm{dm}) 2 \times 5 \mathrm{dm} 2$

$\mathrm{Va}=15,7 \mathrm{dm} 3$

$\mathrm{w}=\mathrm{Va} \times \mathrm{y}$

Keterangan :

Va: kapasitas adonan

$\mathrm{y}$ : berat jenis air $=1 \mathrm{~kg} / \mathrm{dm} 3$ Massa tabung dalam = $5 \mathrm{~kg}$

Jadi beban yang diterima poros adalah :

$\mathrm{W}=$ massa air + massa tabung $=20 \mathrm{~kg}+5 \mathrm{~kg}$

$=25 \mathrm{~kg}($ dimana $\mathrm{g}=10 \mathrm{~m} / \mathrm{s} 2)$

$=25 \mathrm{~kg} \times 10 \mathrm{~m} / \mathrm{s} 2$

$=250 \mathrm{~kg} \mathrm{~m} 2 / \mathrm{s} 2$

$=250 \mathrm{~N}$

Kecepatan keliling tabung adonan

$\mathrm{V}=\pi \times \mathrm{D} \times \mathrm{N}$

$\mathrm{V}=\pi \times \mathrm{D} \times \mathrm{N}$

$=3,14 \times 0,2 \times 44$

$=27,6 \mathrm{~m} / \mathrm{min}$

Gaya yang terjadi adalah

$\mathrm{F}=\mu \mathrm{xW}$

$\mathrm{F}=\square \mathrm{x} \mathrm{W}$

$=0,3 \times 250$

$=75 \mathrm{~N}$

$\mathrm{T}=\mathrm{F} \times \mathrm{r}$

$\mathrm{T}=\mathrm{F} \times \mathrm{r}$

$=75 \times 0,0625$

$=4,6875 \mathrm{~N}$

Daya motor $(\mathrm{P})$

$\mathrm{P}=(2 \pi \times \mathrm{N} \times \mathrm{T}) / 60$

$\mathrm{P}=(2 \pi \times \mathrm{N} \times \mathrm{T}) / 60$

$=(2 \times 3,14 \times 44 \times 4,6875) / 60$

$=21,5875 \mathrm{~W}$

$=0,0215875 \mathrm{KW}$

$=0,028 \mathrm{HP}$

Jadi beban yang diterima oleh poros adalah 0,028

HP. $\mathrm{P}$ total $<\mathrm{P}$ rencana, maka untuk pemilihan motor dengan $0,25 \mathrm{HP}, 1310 \mathrm{rpm}$ sudah memenuhi syarat.

\section{Menghitung torsi pada pulley}

Pada mesin rujak es krim otomatis berbaasis pneumatik ini pulley digunakan untuk menghubungkan poros pada motor ke gearbox.Analisa perhitungan diperoleh data-data sebagai berikut :

Daya motor $(\mathrm{P})=0,25 \mathrm{Hp}$.

Kecepatan putar $(\mathrm{N} 1)=1310 \mathrm{rpm}$.
Koefisien gesek $=0,3$.

Diameter pulley motor $(\mathrm{D} 1)=75 \mathrm{~mm}$.

Diameter pulley input speed reducer $(\mathrm{D} 2)=75 \mathrm{~mm}$.

Dari data diatas sudah terlihat besar diaeter pully yang digunakan adalah sama, jadi putaran motor yang keluar dan putaran yang masuk ke input gearbox adalah sama, yaitu 1310 rpm.

\section{Menghitung Panjang Keliling Sabuk V-Belt}

Untuk menghitung panjang keliling sabuk V-belt menggunakan rumus sebagai berikut:

$\mathrm{L}=2 \mathrm{C}+\pi / 2\left(\mathrm{~d} \_\mathrm{p}+\mathrm{D} \_\mathrm{p}\right)+1 / 4 \mathrm{C}\left(\mathrm{D} \_\mathrm{p}-\mathrm{d} \_\mathrm{p}\right) \square 2$

Keterangan:

$\mathrm{L}=$ Panjang keliling sabuk V-belt (mm)

$\mathrm{C}=$ Jarak sumbu poros ( $\mathrm{mm})$

$\mathrm{dp}=$ Diamer pulley penggerak $(\mathrm{mm})$

$\mathrm{Dp}=$ Diameter pulley yang digerakkan $(\mathrm{mm})$

Diketahui:

$\mathrm{C}=265 \mathrm{~mm}$

$\mathrm{dp}=75 \mathrm{~mm}$

$\mathrm{Dp}=75 \mathrm{~mm}$

Maka: $\mathrm{L}=2 \mathrm{C}+\pi / 2\left(\mathrm{~d} \_\mathrm{p}+\mathrm{D} \_\mathrm{p}\right)+1 / 4 \mathrm{C}\left(\mathrm{D} \_\mathrm{p}-\mathrm{d} \_\mathrm{p}\right) \square 2$

$=2(265)+3,14 / 2(75+75)+1 /(4 \times 265)(75-75) \square 2$

$=530+3,14 / 2(150)+1 /(4 \times 265)(0) \square 2$

$=530+235,5+0,0009$

$=765,5009 \mathrm{~mm}$

Jadi, panjang keliling sabuk V-belt pada mesin rujak es krim adalah $765,5 \mathrm{~mm}$.

\section{Perhitungan Biaya}

Biaya pembuatan mesin es krim pada mesin rujak es krim otomatis berbasis pneumatik terdiri dari biaya pembuatan dan biaya bahan baku. Rincian biaya proses produksi mesin es krim pada mesin rujak es krim otomatis berbasis pneumatik adalah sebagai berikut.

\section{Perhitungan Biaya Mesin es krim}

Perancangan menggunakan Bill of Material (BOM) adalah untuk mengetahui kebutuhan material yang menyusun terbentuknya suatu produk.

\section{Bagian Rangka}

Rangka yang dibuat mampu menahan beban sebesar $25 \mathrm{~kg}$. Material yang digunakan untuk membuat rangka adalah baja ST 37 profil hollow dan profil L yang berukuran $40 \times 40 \times 1,6 \mathrm{~mm}$. Mesin mempunyai dimensi 900 x 500 x $950 \mathrm{~mm}$.

\section{Dudukan motor penggerak}

Dudukan motor adalah tempat bertumpunya motor, yang nantinya motor dan dudukan ini akan disatukan

Teknologi Tepat Guna 
dengan cara dibaut. Bahan dudukan yang digunakan adalah profil $\mathrm{L} 3 \mathrm{~cm} \times 3 \mathrm{~cm}$

\section{Dudukan gearbox}

Dudukan gearbox adalah tempat bertumpunya gearbox yang dipasang dengan cara dibaut. Bahan dudukan yang digunakan adalah plat baja ST 37 dengan ketebalan $3 \mathrm{~mm}$.

\section{Mur dan baut}

Mur dan baut digunakan untuk mengunci motor, gearbox dengan rangka. Adapun baut yang digunakan adalah baut M 10 yaitu baut dengan lubang kunci $10 \mathrm{~mm}$.

\section{Bagian mekanis}

\section{Motor}

Motor yang digunakan mempunyai spesifikasi 0,25 Hp dan putaran $1310 \mathrm{rpm}$.

\section{Gearbox}

gearbox digunakan untuk mereduksi putaran motor dengan perbandingan 1:30 dari $1310 \mathrm{rpm}$ menjadi 44 rpm.

\section{Pulley}

Bahan pulley yang direncanakan adalah jenis alumunium karena memiliki kelebihan ringan dan dapat mengurangi beban.

\section{V-belt}

V-belt yang digunakan adalah sabuk V tipe A.

\section{Poros}

Bahan poros yang digunakan adalah jenis baja karbon S35C-D dengan diameter $25 \mathrm{~mm}$.

\section{Tabung}

Tabung berfungsi sebagai tempat adonan yang diputar melalui poros, dengan dimensi tinggi 500 $\mathrm{mm}$, dan diameter $200 \mathrm{~mm}$.

\section{Perhitungan biaya perancangan mesin es puter Biaya bahan baku}

Biaya bahan baku adalah biaya pembelian komponen-komponen yang dibutuhkan mesin es krim pada mesin rujak es krim otomatis berbasis pneumatik. Adapun rincian dari bahan baku dijelaskan pada tabel dibawah ini:

Tabel 1. Biaya bahan

\begin{tabular}{|c|l|c|c|lr|}
\hline No & \multicolumn{2}{|c|}{ Komponen } & Jumlah & Harga & \multicolumn{2}{c|}{ Total } \\
\hline 1 & hollow & $12 \mathrm{~m}$ & & $\mathrm{Rp}$ & 300.000 \\
\hline 2 & Motor 0,25 Hp 1310 rpm & $1 \mathrm{buah}$ & & $\mathrm{Rp}$ & 700.000 \\
\hline 3 & V-belt & $1 \mathrm{buah}$ & & $\mathrm{Rp}$ & 40.000 \\
\hline 4 & Pulley & 2 buah & & $\mathrm{Rp}$ & 100.000 \\
\hline 5 & gearbox & $1 \mathrm{buah}$ & & $\mathrm{Rp}$ & 800.000 \\
\hline 6 & Besi poros & $1 \mathrm{~kg}$ & & $\mathrm{Rp}$ & 50.000 \\
\hline 7 & siku & $6 \mathrm{~m}$ & & $\mathrm{Rp}$ & 150.000 \\
\hline 8 & Bearing Ucf & 1 buah & & $\mathrm{Rp}$ & 50.000 \\
\hline 9 & Mur dan baut & 12 buah & & $\mathrm{Rp}$ & 100.000 \\
\hline \multicolumn{2}{|c|}{ Total } & & $\mathrm{Rp} 2.290 .000$ \\
\hline
\end{tabular}

\section{Biaya pembuatan}

Biaya pembuatan adalah semua biaya yang dikeluarkan untuk membayar jasa pembuatan di bengkel. Adapun rincian dari biaya pembuatan dijelaskan pada tabel di bawah:

Tabel 2. Biaya pemakaian dan biaya operator

\begin{tabular}{|c|l|r|l|c}
\hline No & Jenis mesin & $\begin{array}{r}\text { Waktu } \\
\text { pemakaian }\end{array}$ & $\begin{array}{l}\text { Sewa mesin } \\
\text { (/jam) }\end{array}$ & Total biaya \\
\hline 1 & mesin bubut & & & $\operatorname{Rp~200.000~}$ \\
\hline 2 & Mesin Frais & & & $\operatorname{Rp~} 100.000$ \\
\hline 3 & Mesin Las & & & $\operatorname{Rp~300.000~}$ \\
\hline 4 & Mesin Bor & & & $\operatorname{Rp~50.000~}$ \\
\hline 5 & Mesin Gerinda & & & $\operatorname{Rp~150.000~}$ \\
\hline 6 & Finishing & & & $\operatorname{Rp~} 950.000$ \\
\hline \multicolumn{2}{l}{} \\
\hline
\end{tabular}

\section{Proses sistem Kerja Mesin Rujak Es Krim supaya Kinerja Maksimal}

Pada hal ini tentang memanfaatkan sistem kerja pneumatik secara maksimal dan menerapkan pada mesin pembuat Rujak Es Krim, lihat gambar di bawah:

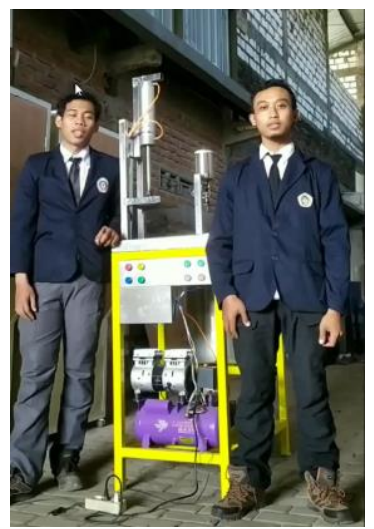

Gambar 10. Mesin Pembuat Rujak Es Krim

Teknologi Tepat Guna 
Untuk mendapatkan sistem kerja pneumatik yang maksimal kami menggunakan beberapa komponen yang bisa mendukung sistem kerja pneumatik secara maksimal. Berikut adalah komponen pendukung sistem pneumatik : Kompresor, Katub control, Timer menegement, Sensor proxy, seperti dapat di lihat pada gambar di bawah ini:

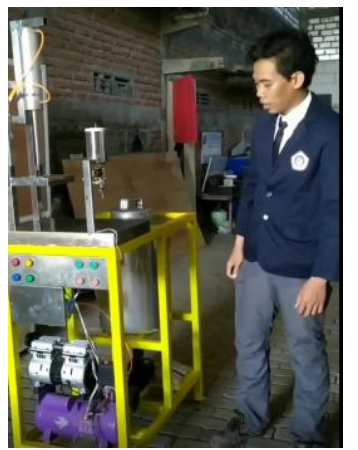

Gambar 11: Sistem Kerja Mesin Rujak Es Krim

Semua komponen diatas menggunakan diagram alur. fungsi dan kegunaan dalam mesin kami yaitu mesin pembuat Rujak Es Krim. Dimulai dari kompresor yang terdapat pada mesin pembuat Rujak Es Krim yang dipakai tidak membutuhkan ruang yang banyak, tegangan listrik tidak telalu tinggi, dan menghemat biaya, lihat gambar di bawah ini:

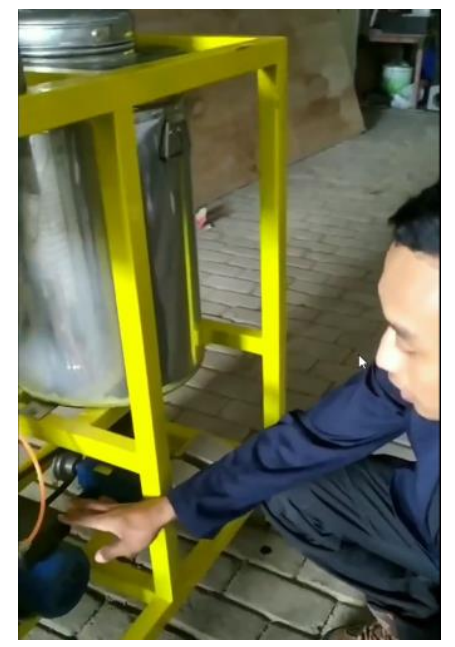

Gambar 12: Sistem Kerja Kompresor

Katub kontrol Tabung Es Krim yang terdapat pada mesin pembuat Rujak Es Krim. Kami menggunakan katub kontrol popet atau katub kontrol duduk yang tipe $2 / 2$ sederhana pada umunya. Dengan mengunkan katub ini kami bisa mengontrol keluar masuknya udara yang ada tabung pneumatik. Kami bisa mengontrolnya sesuai keinginan dan kebutuhan mesin kami. Dengan begitu kinerja sistem pneumatik yang ada di mesin kami bisa maksimal dan sempurna, lihat gambar di bawah ini.

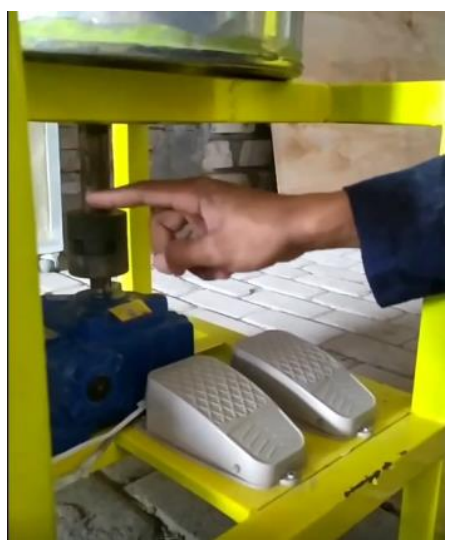

Gambar 13: Pedal Katub Tabung Es Krim Timer menegement yang terdapat pada mesin pembuat Rujak Es Krim. Kami menggunakan timer menegement untuk memudahkan semua proses yang terjadi pada sistem pneumatik di mesin pemotong Rujak Es Krim, lihat gambar di bawah:

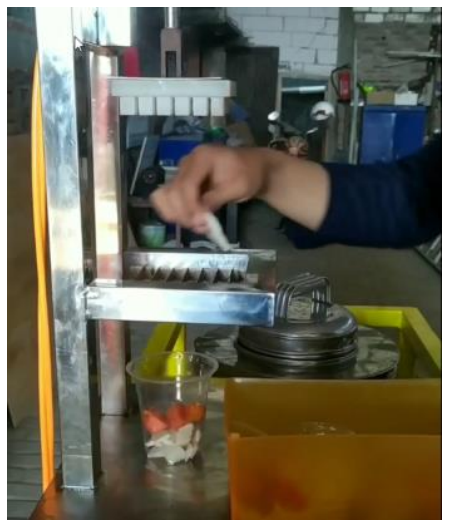

Gambar 14. Pemotong Buah Rujak Es Krim

Dengan menggunakan timer menegement kita selaku pengguna sudah tidak perlu repot - repot untuk mengatur waktu yang dibutuhkan dalam sebuah proses yang terjadi pada bumbu Rujak Es Krim. hanya perlu mengatur waktu yang kita butuhkan dalam satu proses

Teknologi Tepat Guna 


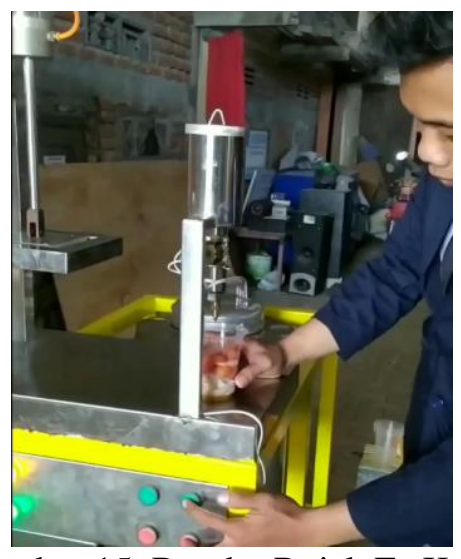

Gambar 15. Bumbu Rujak Es Krim

Yang nantinya timer menegement akan mengontak sensor proxy untuk melakukan langkah atau step selanjutnya.

Semua proses sistem pneumatik yang terdapat pada Bumbu Rujak Es Krim di kontrol dari panel kontrol yang terdapat didalam mesin pembuat Es Krim.

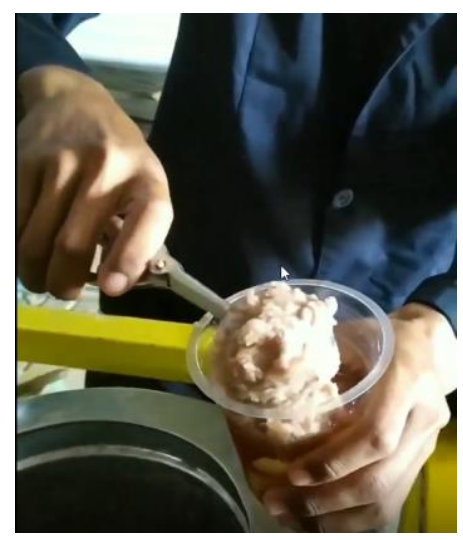

Gambar 16. Hasil Rujak dan Es Krim

\section{KESIMPULAN}

Kesimpulan berisi rangkuman hasil kegiatan pengabdian kepada masyarakat dan implikasi dari kegiatan yang dilaksanakan sebagai berikut :

1. Pengabdian Masyarakat ini telah menghasilkan sebuah mesin ukm bagi masyarakat yang dapat memudahkan para penjual rujak es krim dalam pembuatan produk yang dijual.

2. Mesin es krim yang sudah jadi ini memiliki penggerak di bagian bawah, sehingga dalam pembuatan es krim tidak kesulitan saat menambahkan es dan garam sebagai pengawet adonan es krim.

Saran

1. Poros pada pemutar tabung es krim seharusnya memakai bahan stainless agar mencegah adanya korosi.

2. Kran pembuangan air es yang ada pada sisi bawah tabung luar sebaiknya dikasih selang agar air es yang keluar tidak mengenai part yang lain.

\section{UCAPAN TERIMAKASIH}

Ucapan terimakasih disampaikan kepada Fakultas Teknik Universitas Wijaya Putra yang telah memberikan kontribusi dalampelaksanaan kegiatan.

\section{REFERENSI}

1. Yuniati Yetti, Sri Purwiyanti, Yul Martin. 2017. Mesin Pembuat Es Puter Elektrik untuk Home Industry di Wilayah Rajabasa Bandar Lampung. Bandar Lampung : Proceeding of Community Development. Volume 1 ISSN No. 2615-2924

2. Annishia,Fristi Bellia, Setiawan Dhanarindra. 2017. Uji Banding Emulsi Pembuatan Es Krim: Kuning Telur Dengan Gelatin. Jakarta Timur. Jurnal Hospitality dan Pariwisata. Vol.3(No.2). ISSN : 2442-5222

3. Sistanto, E. Sulistyowati, Yuwana.2017.Pemanfaatan Limbah Biji Durian (Durio zibethinus Murr) sebagai Bahan Penstabil Es Krim Susu Sapi Perah. Jurnal Sain Peternakan Indonesia. Vol. 12 No. 1. pISSN1978-3000 e-ISSN 2528-7109

4. Samhuddin, Muhammad Hasbi, Jamiluddin. 2018. Perencanaan sistem transmisi alat peniris pada mesin pengering helm. ENTHALPYJurnal Ilmiah Mahasiswa Teknik Mesin. Vol. 3, No. 1. e-ISSN: 2502-8944

5. Ermawati, Wa Ode, Sri Wahyuni, Sri Rejeki. 2016. Kajian pemanfaatan limbah kulit pisang raja (musa paradisiaca var raja) dalam pembuatan es krim. J. Sains dan Teknologi Pangan. Vol. 1, No. 1, p. 67-72, Th. 2016

$$
\text { Teknologi Tepat Guna }
$$


ISSN:2527-6271

6. Surya Indra ,Tri Pujianto. 2018. Perancangan alat pemipil jagung. Jurnal Teknik Mesin UBL, VOL.5 NO. 2. ISSN 2087 - 3832

7. Nasution Ahmad Yunus, Gunawan Hidayat. 2018. Rancang bangun alat pengaduk adonan bubur organik kapasitas 7 liter untuk industri UMKM. Jurnal Mesin Teknologi (SINTEK Jurnal) Volume 12 No. 2. ISSN: 2088-9038, eISSN: 2549-9645

8. Mustamin, Muhammad Hasbi, Al Ichlas Imran. 2019. Perancangan Mesin Perajang Singkong. Jurnal Ilmiah Mahasiswa Teknik Mesin. Vol. 4, No. 1. e-ISSN: 2502-8944

9. Sularso dan Kiyokatsu Suga. 2002. Dasar
Perencanaan dan Pemilihan Elemen Mesin Jakarta: PT. Pradnya Paramita

10. Muslim. 2017. Redesain mesin pemutar dan revitalisasi manajerial pengusaha es krim di Medan. Jurnal Pengabdian Kepada Masyarakat. Volume 23 Nomor 3. p-ISSN: 0852-2715 | eISSN: 2502-7220

11. Widiyatmoko. 2015. Perancangan, perakitan, dan pengujian performa mesin pembuat es krim manual kapasitas 5 liter. Jurnal Teknologi Pendingin dan Tata Udara Politeknik Sekayu (PETRA). Volume 1, No. 1 ISSN-P 2460-8408 12. (http//.www. id.m.wikipedia.org/wiki/kopling) di akses pada 2 Mei 2020. 